\title{
Basque Education Rights and European School Systems
}

\author{
Fito Rodríguez Bornaetxea
}

Department of Theory and History of Education, Faculty of Philosophy and Educational Sciences, University of the Basque Country (UPV/ EHU), Donostia/San Sebastian, 20018, Spain

Copyright (C) 2015 Horizon Research Publishing All rights reserved.

\begin{abstract}
It is impossible to achieve the normalization of Basque schools when they are subjected to five sets of regulations on the use of the Basque language in different parts of Euskal Herria. Instead of an education system that differentiates between various language models, what is needed is a school system that recognises the right of all Basque children to be educated in Basque and provides the necessary means to achieve this. As in Finland, Quebec or Belgium, so in Euskal Herria too it should be a given that all future university graduates must know the national language. The road to independence is incomplete without education in Basque. This chapter explores ways to improve this situation by looking at how things are done in Finland, in particular, and in the Netherlands and Estonia.
\end{abstract}

Keywords Basque Education Rights, Public Education

\section{Introduction}

Each of the two states responsible at present for Euskal Herria's education system has endeavoured to implant its own culture at the expense of a hypothetical Basque school curriculum; this has had, and still has, consequences for education policy and legislation which make themselves felt in the biased language-support structure and also when attempting to ensure balanced development of a teaching community. To begin with, the French national school system has never consented to give assistance to school systems outside its own system. And in the kingdom of Spain the only recognised language of education is Castilian. The whole educational structure has been organised in accordance with the two states, ignoring the educational needs of Euskal Herria historically and imposing the states' education policy.

State-building in France and Spain led to the choice of a single language and culture among those found in each state's territory, and its development. The languages and cultures that were not chosen were thus displaced or even forbidden. Consequently Breton, Alsatian and Occitan were not able to have a state-supported school system, and neither could Catalan, Galician and Basque. These languages were excluded from the official public education system. This is by no means the only example of the use of a school system to force an alien culture on people. In the United Kingdom, for exlample, Gaelic, Scots Gaelic and other Celtic languages were excluded from the public school system; in Belgium, Flemish (Dutch) did not receive proper treatment in public education until Belgium became a federal kingdom (in 1932, in Flanders, there were 108 public schools and 101 private schools, all of which only taught French) (Rodriguez, [10]).

The French national education system has never consented to give any assistance to the schools outside its own system. The words of Barère, spoken in 1794, still echo today:

"Le fédéralisme et la superstition parlent bas breton, l'émigration et la haine de la République parlent allemand, la contre-revolution parle italien, et le fanatisme parle basque. Cassons ces instruments de dommage et d'erreur." [Federalism and superstition speak Breton; emigration and hatred of the republic speak German; the counter-revolution speaks Italian, and fanaticism speaks Basque. Let us break these harmful instruments of error.] In the whole history of educational legislation (e.g. Mirabeau 1740-1791, Talleyrand 1758-1838, Condorcet 1743-1793) and especially Napoleon Bonaparte's educational reform (1799-1815), there is never a good word spoken for anything outside of French culture, just negation and exclusion. A decree of the 17th of November, 1794, established that primary schooling anywhere in France must be in French. In a recommendation emitted by the Bayonne city council in April, 1796, and in another from the prefect of Maule in 1802 , it is laid down that only French is to be used in schools. The same thing was repeated by the prefect of Donibane Garazi in 1819, and thus Basque was persecuted throughout the northern Basque Country: "J'ai exigé des instituteurs l'abolition entière de l'usage de la langue basque en classe" (Maule school inspector, 1833); "Le Réglement interdit de parler basque" (Donapaleu committee, 1846). In such ways as this Basque was systematically pushed out by French: "Nos écoles au Pays Basque ont particulièrement pour objet de substituer la langue française au basque» (prefect of Bas-Pyrénées, 1846). Not only has France's national education system never accepted any culture or language but its own in the public school system, it even refused all 
assistance to initiatives outside the public system up until the publication of the legal agreement of the 11th of December, 1959 , when the national system began to hand out subsidies to so-called 'private schools' on a one-by-one basis (Rodriguez, [7]).

In the kingdom of Spain, too, Castilian was the only acceptable language of instruction: "Mando que la enseñanza de las primeras letras se haga en lengua castellana generalmente y dondequiera que no se practique, cuidando de su cumplimiento las audiencias y justicias respectivas para su exacta observancia y diligencia en extender el idioma general de la nación" (Article VIII of an order given by King Carlos III on the 23rd ofJune, 1768). [I command that primary education shall be carried out in the Castilian language generally and wherever it is not practised, compliance with which being supervised by the respective courts in order that this be exactly observed, taking care to spread the general language of the nation.] When the Moyano Law was passed, it became absolutely clear that Castilian was to be the only language admitted in education: "The grammar and spelling of the Academia Española shall be the obligatory and exclusive text for these subjects in public education" (Article 85 of the Ley Moyano or Law of Public Instruction, 7th of September, 1857).

Some school textbooks in Basque were subsequently published, e.g. in the south, Diálogos basco-castellanos para las escuelas de primeras letras, Iturriaga 1842; Diccionario manual vascongado y castellano, Astigarraga 1825; Método práctico para enseñar el castellano en las escuelas vascongadas, Eguren 1867; and in the north, Uskara eta franzes gramatika uskalerrietako haurrentzat egiña, Archu 1852. But all these books were bilingual; their purpose was to wean pupils away from Basqe, and they were used to teach Spanish or French to monolingual Basque-speaking children (who were the majority) (Rodriguez, [8]).

What is more, the entire organisation of education was as determined by the two states: in Spain's case, this was in accordance with a decree of 1874 . The local authorities lost their competence to hire schoolteachers. A statewide teaching profession was established, training and qualifications for which were under state control and have remained so to this day; since 1902 in Spain. Article 26 of the 1988 Declaration of Human Rights states that all people have a right to receive an education without any kind of discrimination. Throughout history, Basques have been denied the possibility of taking responsibility for the fulfilment of this right.

\section{Analysis of the Present Situation}

Article 20 of the 1978 Spanish Constitution, the purpose of which is purportedly to ensure educational freedom, nonetheless places strict limits on the possibility of developing Basque education. Article 27, on the other hand, addresses educational rights. According to the latter, the state of Spain reserves the option to guarantee that all
Spaniards's educational rights are respected and speak on powers covering local languages and education.

Accordingly, although there are two different politically autonomous regions in southern Euskal Herria which both have powers in education, competence to organise the education system as a whole belongs to the state. In consequence, Euskal Herria is denied the ability to organise its own education.

The French Republic, as we have seen, does not share its powers over education with anyone. The only national education and language are French education and the French language. In Spain, on the other hand, control of education is determined in Articles 20, 27 and 149 of the Spanish Constitution together with a set of more specific laws. All this is limited by Article 148 of the Constitution. So let us see what limits this places on education in the southern Basque Country.

Although Article 20 of the 1978 constitution claims to ensure freedom of education, it establishes narrow limits. The most basic point is that it forbids any criticism of the Spanish Constitution in non-university education (Antonio Embid Irujo, 1984); that rules out making any claims on behalf of Euskal Herria.

Article 27, on the other hand, addresses educational rights. According to this article, the Spanish state reserves the right to guarantee that all Spaniards's educational rights are respected and to speak on powers concerning local languages and education: "Velar por el cumplimiento de las condiciones básicas que garanticen la igualdad de todos los españoles en el ejercicio de sus derechos y deberes en materia de educación, así como de sus derechos lingüísticos, y en particular el derecho de recibir enseñanza en la lengua oficial del estado" (Royal Decree 4801981 of the 6th of March on the High Inspectorate of State for non-university education in the Basque Country and Catalonia). [Ensure compliance with the basic conditions guaranteeing the equality of all Spaniards in the exercise of their rights and duties in education, as well as their language rights, particularly the right to receive education in the official state language.] Briefly put, Spain retains as its own the following powers in education:

1. Organisation of the education system: the power to create structures (levels, cycles and the relationships between them), conditions and criteria for teachers, schooling periods, school organisation, average for pupils in formal education...

2. Minimum teaching contents: curriculum objectives and content, criteria for evaluation, general requirements for textbooks...

3. Design of qualifications or equivalences: syllabuses, minimum credits, core subjects, fields of study...

4. Teaching structure: staff positions, resources, etc.

5. Superior inspectorate: ways to check whether the above conditions are being met, investigate whether there is discrimination against Spanish pupils, check whether requirements for obtaining qualifications are being complied 
with.

Apart from this, there are clauses relevant to education in the Gernika Statute (Organic Law 3-1979) and the Law of Improvement of the Regime of Navarre (Organic Law 131982); these lay out the basic powers of the governments of the Basque Autonomous Community and the Community of Navarre respectively. In the Gernika Statute there are three such articles: Article 6 (on the official status of the language), Article 10 (on culture in general) and Article 16, which is directly concerned with education. The pertinent parts of the Navarrese law are articles 9,44 and 47. The determinations on transfers of powers in education contemplated in Article 148 of the Spanish Constitution are fleshed out in these legislative documents.

However, those transferred powers are subject to conditions laid down in the constitution's Article 149, which lists the powers which the state retains for itself, which include control of the civil service (teachers in the Spanish public school system have the status of civil servants), the ability to issue qualifications and responsibility for school inspectors.

Civil servants in the public school system, however, have been covered by special state powers since the Bravo Murillo Law of 1852, although the general law in effect in the southern Basque Country governing this dates from 1918 and was amended in 1964 and confirmed again in the 1978 constitution. In northern Euskal Herria, the 1946 Law of Public Service amended after the Second World War remains in force to this day.

Accordingly, although there are two different autonomous communities in southern Euskal Herria which both have powers over education, the power to organise the education system in its entirety remains in the hands of the state. Hence the following are not controlled by the Basque Country:

1. Organisation of the education system, including the power to:

1.1. Create structures (levels, cycles and the relationships between them).

1.2. Determine conditions and criteria for teachers.

1.3. Decide schooling periods.

1.4. Organise schools.

1.5. Average for pupils in formal education.

2. Minimum teaching contents:

2.1. Choose Basque as the only language of education.

2.2. Set curriculum objectives and content.

2.3. Determine the criteria for evaluation.

2.4. To legislate general requirements for textbooks.

3. Design of qualifications and their equivalences.

3.1. Determine syllabuses autonomously.

3.2. Decide core subjects and fields of study.

4. Freedom to organise the teaching structure.

4.1. Employ school staff.

4.2. Provide for teaching resources.

5. A superior inspectorate to check whether the above conditions are being met, investigate whether there is discrimination against Basque-speaking pupils, check whether requirements for obtaining qualifications are being complied with.

This list contains competences attributed to itself by any state in order to ensure that educational rights are provided for, yet despite the transfer of powers over education in the southern Basque Country, these powers are denied to the Basque Country; these rights remain to be conquered.

\section{Looking towards the Future: A Proposal}

The normalisation of Basque education is impossible as long as Basque is subject to five different sets of administrative regulations in the territory of Euskal Herria. With regard to language use in instruction, we demand a school system which will ensure respect for the right of all children in the country to be educated in Basque. To achieve this, there is a need for a Basque system, that is, the right to give out qualifications and the ability to organise teachers.

This leads to the need for a reform of schools and faculties for the training of teachers. The University should ensure, as in Finland, Quebec or Belgium, that all newly qualified teachers know the country's national language. A Basque education is necessary for the road to independence. To outline that road we shall note in particular the case of the education system adopted by Finland, while also looking at what has been done in the Netherlands and Estonia. These countries, starting from an initially bilingual sociolinguistic situation, have successfully extended the proper fulfilment of the right to education, and all have now attained top marks in education quality, with good reasons to foresee excellent perspectives for the future.

\subsection{Education in Finland Education in Finland Education in Finland}

We may conclude from a comparison of PISA statistics between countries that at age fifteen Finns have the highest scores anywhere in reading, mathematics and science. From that point of view, the Finnish school system may be considered a model for imitation. Of course many other aspects should also be evaluated to determine the bill of health of education, not just these skills. In any case, there is much to be learnt from the Finnish example, which has often been noticed by Basques. Many teachers, principals and educators from the Federation of Teaching Cooperatives of Euskadi and HETEL have been there on visits. They have seen the Finnish schools in action, studied them, evaluated them and analysed what can be learnt from them in the Basque Country (Hik Hasi, [2]).

\section{Key Features}

In many countries in the world, giving children a school education or making them literate is an objective that has not 
been achieved in its totality. In other countries, all children can read and write and go to school; this basic right has been fulfilled. For these countries the big challenge is to improve the education system: its resources and infrastructure, pedagogical issues, the situation of the staff and the pupils, participation and so on. Many measurements are made to quantify the state of health of education systems.

One of these is PISA, the Programme for International Student Assessment. This study is performed once every three years. The first took place in 2000 , and forty-three countries were took part. The second was carried out in 2003 in forty-one countries and the third in 2006 in fifty-eight countries. PISA evaluates reading, mathematics and science skills. The results to date show that the Finnish school system has achieved the highest ranking.

Fifteen-year-old Finnish pupils achieved better scores in 2003 than in 2000 in the mathematics and science sections. In reading Finland remains in the first place. Finish pupils have achieved the best results in "the key competences related to knowledge and skills for life". What is more, when compared to other countries, the system in Finland shows the greatest degree of equity between students. There are fewer differences between girls and boys, or between schools among the regions, in Finland than in other countries. So what is the Finnish system's secret for achieving such good results? How is it organised, and how do they train their teachers? Here are some of the facts to explain this success: Finland is a country of 5,200,000 inhabitants. There is a high level of social cohesion and homogeneity among the population. It has the highest literacy rate, at $100 \%$. It may be said that there was no literacy at the start of the twentieth century. Education has been fundamental to this country which lived under Swedish and Russian domination for centuries. Education has been the road to the maintenance of a national identity and the achievement of independence.

Educators' university training: Teachers are able to update their training through in- service courses as regulated by local councils. Courses are provided with assistance from the central government. But less importance is attached to this than to teachers' initial training. Anyone who wants to be a teacher must go to university. This is considered important.

Places at university fall short of demand, and only 10$15 \%$ of the applicants get in.

Three basic qualifications are offered by the university:

- Infant Education diploma: courses last between two and three years.

- Primary Teachers: studies last between four and five year.

- Teachers of specific subjects or areas: teachers are responsible for one or two subjects at compulsory secondary school level. The university recognises two possible routes:

1. Subject-based: mathematics, chemistry, geography etc.

2. Teaching-focused: special training focusing on preparation for the teaching profession, provided by the faculty of education.

There are also many Masters degrees for specialisation, including special education, arts, music and domestic economics.

All specialisations share 35 credits in core education-related subjects, and it is here that the general principles of educators' training are defined:

- Training based on research projects: there is ongoing cooperation between those who perform research and those who put it into practice from the beginning of the programme.

- Practicum: a practical component is done at all levels and in all stages. For every module that they complete, trainees perform some kind of activity, such as an observation or an internship, to see the things that they have learnt in theory put into practice. The content and objectives of the practice component are related to the programme syllabus. Trainees begin as observers and by the end they perform a real, professional assistanceship, acting as teachers and taking part in all school activities, including teachers' meetings. They can keep track of a class of pupils year by year and follow the group's evolution.

- Theory and practice are closely linked. Based on their theoretical knowledge, they learn to seek solutions to the challenges that arise each day at work. They do not limit themselves to a single methodology, but develop several methods so that they can choose the most suitable one later when they are working.

\section{Council Involvement}

Town councils have an important function. The council plans, builds and maintains schools. The council hires school staff (always supervising the principal's work). It also hires the principal. The council is in the last resort responsible for the good working of the school and is its owner. It establishes the principles governing the school's autonomy.

The school and its staff (especially the principal's office), for their part, are answerable to the council for the functioning of the school. Teachers have a great deal of autonomy in the school's functioning and to implement and adapt the national curriculum.

Although under the supervision of the principal and the council, they are not limited by them.

The different sectors of the school take part in the school's committees and also in their town's education commission.

\section{Decentralisation}

One of the features of the Finnish education system is decentralisation. They have carried out a twenty-year decentralisation system for the purpose of improving their system of education. Currently the functions carried out by the authorities are as follows:

Ministry of education: 
- Educational legislation and strategy.

- Development of education plans.

- Budgets for education.

- General objectives.

- Achievement targets.

- European and international agreements.

National Education Commission (a commission made up of education experts which assists the ministry of education):

- Design of curricula for each level.

- Evaluation of skills and study programmes.

- Education management systems.

- Services for the ministry, schools, educators etc.

Local administration, education commissions and inter-city federations:

- Local and regional strategy.

- Local school system.

- Local curriculum.

- Hiring of teachers, principals and other services.

- Organisation of enrolment.

- What schools delegate to other entities varies from place to place.

\section{Entrance Exams}

However, it was the impression of the Basque visitors that choices become much more limited beyond the level of compulsory education. Thirty to thirty-five percent of applicants who wish to study for the equivalent of A-levels are turned down. According to the experts, "each secondary school has its own entrance exams; some take into consideration the applicant's marks for the last three years, others set different exams depending on the area of specialisation, still others require a minimum mark." "[In the Basque Country] there are more opportunities for higher studies. Whatever one thinks about whether or not it is a good idea to have so many people with degrees, the fact is that the opportunities are greater here" (Hik Hasi,[2]).

A-level schools are specialised. Vaskivuori School in Vantaa, for example, specialises in music and dance. The core curriculum which is obligatory for all pupils covers 63$68 \%$ of the timetable, and the rest is optative. There is a very flexible schedule and individual pupils program their own modules. The A-level programme usually lasts three years but some do it in two years, some in four.

\section{Occupational Colleges}

Individuals who have no official qualification but demonstrate that they have mastered a trade can be recognised by the occupational schools and in some cases receive a qualification. This scheme, which started ten years ago in Finland, was recently adopted in the Basque Country. $54 \%$ of the population is in in-job training, and this increases the importance of the occupational schools.

\section{Prestige and Training of Teachers}

Given the tough selection process for admission to teacher training, and on account of their university education, teachers are held in high esteem. Only $15 \%$ of student applicants to the Faculty of Education are admitted. "We asked at the university about the reason for the high prestige attaching to the teacher's profession, and were told that the reason is historical," wrote HUHEZI instructor Marian Bilbatua (ibid.). "Finland used to belong to Sweden and Russia, and one of the few areas where they could maintain their own culture was in education. This explains the stress placed by Finns on education."

The study programme is centred around thinking. "The ultimate goal of training is to provide teachers with tools for thinking about and improving the situation and what one does about it," explains Marian. "When students start their degree they think they know everything, because they have been in school for years. Their main work is to review and analyse that experience, evaluating positively the things that were useful. They must each reflect on their own experience in order to bring about improvements." So the keys to good training are thinking and linking theory to practice.

\subsection{Education in Estonia}

We must go a long way back to find the beginnings of the Estonian education system. The history of formal education in Estonia starts when the first schools were founded in the thirteenth century. At the time, Estonia was controlled by German and Danish feudal lords, and the education system is linked to the vicissitudes of history as Estonia changed hands between Finland, Sweden, Germany and Russia. Getting an education has always been very important to Estonians. The first Estonian university, the University of Tartu, was established in 1632, and by the end of the eighteenth century two out of three Estonians could read, while according to the 1881 census $90 \%$ of Estonians were then literate. Now, after independence, the education system has two main goals: one is for all children to go to school; the other is to win over to Estonian all children with another native language. The education system in Estonia was already closely linked to the language before independence: during the period of Soviet occupation (1940-1990) the schools fought hard to be able to teach in Estonian, because Russia had established that Russian was to be the language of education. Today the Russian community is an important minority in Estonia:

$26 \%$ of the population is Russians, and in the capital, Tallinn, they make up half the population. Since it became independent Estonian is the only official language of this Baltic republic, and it is also the language of school. In compulsory education, from ages seven to fifteen, at least $60 \%$ of classes must be taught in Estonian so that pupils will be able to do their A-levels and university degree in Estonian. Russian is the second language at school. Interested in the language recovery work being done by the schools, Hik Hasi 
visited Tallinn to take a closer look at the Estonians' education system.

\section{Organisation of the Education System}

Compulsory education in Estonia is from seven to fifteen years old, but the Estonian education system encompasses infants', primary, secondary, occupational, higher and adult education. Most of the schools were started by the state or local governments, although a few in the capital have been founded with private capital. The ministry of education establishes the general guidelines, which are to create suitable conditions to favour the development of identity, family and the Estonian nation; to favour the development of Estonia's culture, politics, economy and ethnic minorities; to teach good citizenship; and lastly, to provide the conditions for the creation of a national, lifelong tradition of learning. Each town council has an education commission and authority to develop its own education policy. From the age of eighteen months on, children may start school, so infants' schools are for children aged from a year and a half to seven years old.

Today children go to nursery school until they are three years old. But until recently, children stayed at home with their mother, who retained her job and was paid a full salary.

As a result of the financial crisis the terms of maternity pay and leave have worsened, and although a mother's job is kept for her for three years, the state ministry has cut their pay back almost by half. The effects of the crisis are revealed in the figures: in 2003 there were 15,698 children attending school in Tallinn; last year there were 21,512. Thus there has been a rise of almost $40 \%$ in seven years. In the case of infants' schools, the city council pays the school a quantity for each child enrolled, regardless of whether the school is public or private. At present, for example, infants' schools in Tallinn receive 1,279 euros from the council for each pupil. Parents pay 22 euros a month for each pupil. They are charged $€ 1.60$ for each day the pupil eats at school, covering three hot meals. Staff and maintenance costs are paid out of the money provided by the council and parents' monthly fees. From eighteen months to three years old, classes of fourteen children are looked after by two educators, although two to four more children may be brought into a class according to needs. Average attendance is $50 \%$, so about half of the fourteen are in class on a normal day. From age three to seven, there are 24 children and two educators per classroom. Although each infants' school may differ, Estonian infants' schools generally, and particularly the ones visited by Hik Hasi, share some common characteristics. From the youngest age, the education system is based on respect for each child's personality, with learning based on play and democratic coexistence among the children. In addition to teachers the schools also provide psychomotor, music and speech pathology specialists, and it is understood that the children's education is the responsibility of all of these educators, together with their families of course. Consequently, infants' schools nurture a close relationship between the school and the family. To facilitate this, the schools remain open from 7 a.m. to 7 p.m., although formal school hours are from 9 a.m. until 5 p.m. There are some schools (in Tallinn there are three) offering a night-care service for parents who because of their work or other necessities cannot have their children at home overnight.

Now, after independence, the education system has two main goals: one is for all children to go to school; the other is to win over to Estonian all children with another native language. The education system in Estonia was already closely linked to the language before independence: during the period of Soviet occupation (1940-1990) the schools fought hard to be able to teach in Estonian, because Russia had established that Russian was to be the language of education. Today the Russian community is an important minority in Estonia:

$26 \%$ of the population is Russians, and in the capital, Tallinn, they make up half the population. Since it became independent Estonian is the only official language of this Baltic republic, and it is also the language of school. In compulsory education, from ages seven to fifteen, at least $60 \%$ of classes must be taught in Estonian so that pupils will be able to do their A-levels and university degree in Estonian. Russian is the second language at school. Interested in the language recovery work being done by the schools, Hik Hasi visited Tallinn to take a closer look at the Estonians' education system. From the youngest age, the education system is based on respect for each child's personality, with learning based on play and democratic coexistence among the children. In addition to teachers the schools also provide psychomotor, music and speech pathology specialists, and it is understood that the children's education is the responsibility of all of these educators, together with their families of course. Consequently, infants' schools nurture a close relationship between the school and the family. To facilitate this, the schools remain open from 7 a.m. to 7 p.m., although formal school hours are from 9 a.m. until 5 p.m. There are some schools (in Tallinn there are three) offering a night-care service for parents who because of their work or other necessities cannot have their children at home overnight.

There are school for children with special needs all over the state, but if parents prefer

They can put their children into regular schools. In Tallinn for example, there are two special needs schools, but there are thirteen other schools in the city which allow such children to be enrolled provided a ratio is maintained of one special-needs child for every three with normal needs. Each school is free to choose its own pedagogical approach, but certain currents are popular in Estonian schools: these include the Maria Montessori and Loris Malaguzzi (Regio Emilia) methods and the approach of an Estonian called Johannes Käis(1900). This is based on two basic principles: developing a close connection with nature, and using play as 
a basis for learning. Play has a special place in infants' school, being considered a fundamental resource for the education of small children. Children play outside for an hour and half every day, and in spring and autumn when daylight hours are longer there are two such hour-and-a-half outside play sessions per day. Schools are not just the place where content is transmitted: children get three meals a day at school, at 9 o'clock, noon and 3:30, and after lunch all children up to age seven have a nap for an hour and a half or two hours. The school is closely involved with health care, and in addition to playing, sleeping and eating, is also concerned with their physical exercise: during the extremely cold Estonian winter saunas are used with all pupils to make them sweat:

Children from 18 months to three years old spend ten minutes in a $60^{\circ} \mathrm{C}$ sauna, while children between three and seven spend twenty minutes at $65^{\circ} \mathrm{C}$. There is a first-aid kit in every classroom and a nurse for each school. In addition to playtime, the current lesson plan is based on four components: play, creativity, nature and culture. The schools are important tools for transmitting Estonian culture, both by revitalising and teaching the language and transmitting the culture itself, especially oral culture. To be a teacher for children from eighteen months to fifteen years, teachers in training must follow a degree level course of studies which takes four years at a university. Over the four years they will have to spend eleven weeks altogether as student teachers.

Candidates for the job of school principal must have a Masters degree as well as a four-year first degree. Then the principal of the school undergoes an evaluation every two years and in the event of failing twice in a row must step down and be replaced by someone else. All teachers must take part in in-job training courses every five years. Furthermore, all teachers undergo an annual internal evaluation following criteria established in 2006 by the ministry of education, and an external evaluation every three years. In addition to evaluation of the director and teachers or staff, there is joint cooperation, with yearly evaluations of the administration's work (especially the budgets) and pedagogical projects. Apart from evaluations, teachers and schools participate in numerous competitions, particularly contests organised by the local council to motivate, make known and stimulate school employees. When the hiring process for jobs begins with the choice of principal, teachers who have, in addition to their degree in Pedagogy, completed a Masters degree that enables them to be a principal receive an announcement of the availability of a principal's position. The principal, once chosen, is given a permanent contract, then the principal chooses the necessary teachers and other members of staff with the assistance of a representative of the council, an education specialist, a teachers' representative and a representative. These representatives all belong to the council's education commission.

Once the teachers are selected they are also given permanent contracts. The same system is followed in public and private schools. In the case of new schools, the local council may make the initial appointments. The basic salary for teachers is 750 euros. This is a hundred euros lower than the average Estonian salary. However, after working for five years they receive a pay rise.

The minimum monthly wage in Estonia is 300 euros. Parents who decide not to send their children to an infants' school at age 18 months are advised to get a carer with a childcaring qualification. These childcarers have done a 160-hour course including subjects on education, psychology, social work, health and safety.

\section{Compulsory Education}

Since 2006 there are 601 schools in Estonia, including 85 infants' schools, 264 primary schools, 236 secondary schools and sixteen adults' secondary schools. This is not counting special education schools and occupational colleges. Although most children start school at 18 months, compulsory education starts at age seven in Estonia, and remains compulsory until fifteen. Basic education consists of nine grades and is paid for by the state and the town council. After the nine grades of basic education, pupils go on to compulsory secondary education; a further three years are required for A-level classes. $72 \%$ of pupils who finish their compulsory education opt to continue on to do A-levels, and of these $70 \%$ get into university, while $28 \%$ opt to go to occupational colleges. The remaining $28 \%$ of those who have completed their compulsory education do vocational training, for which there are 48 schools around the country. Occupational education in particular has become stronger in the last eight years, with the creation of networks incorporating both public and private schools which coordinate their course offerings. There are another eighty trade schools in Tallinn targeting pupils who had difficulty completing compulsory education.

Although the ministry of education establishes guidelines and minimum requirements for compulsory education as it does for infants, each school decides what subjects outside the obligatory curriculum it wishes to teach, as well as which parts of the obligatory curriculum it wishes to reinforce. Pupils must pass three state exams in order to obtain a diploma of compulsory secondary education (Pikabea et al., [4])

\subsection{Education in the Netherlands Country Introduction}

The area of the Netherlands is $41,500 \mathrm{~km} 2$, twice that of Euskal Herria. But its population of sixteen million is five times the size. That makes it a country with a high population density. The state's capital is Amsterdam, but the government and ministries are located in The Hague.

There are over three million immigrants in the Netherlands, making up almost $20 \%$ of the population. Half of them are first-generation immigrants, the rest were born in the country and are second-generation immigrants.

Most immigrants are Turkish (22\%), Surinamese (21\%), Moroccan (20\%), Dutch Antilleans (8\%), and many others 
come from the country's former colonies. In speaking of pupils' place of birth the Dutch make a distinction between autochtonen (of Dutch origin) and allochtonen (of non-Dutch origin).

\section{Characteristics of the Education System}

The ministry of education establishes the general lines of the system, providing legislation, funding and monitoring. In other words, the government decides what must be achieved and is responsible for the resources needed to achieve it.

1. Legislation:

- Establishes the conditions which must be met to set up schools.

- Sets requirements for becoming a teacher.

- Specifies a basic curriculum, with 58 general objectives, that pupils must complete by the age of twelve.

2. Funding:

In principle, compulsory education (ages four to eighteen) is free for everyone.

- Sets the amount of money to be assigned per pupil. At the present time, rounding off, the amounts are $€ 4000$ for each pupil in infants' or primary school, $€ 6000$ for those in secondary school, and triple these amounts for each pupil with special needs.

- All teachers receive equal treatment. The same basic pay applies to all, with bonuses for seniority and for teachers aged over 45 .

- Each school spends roughly between $80 \%$ and $85 \%$ of the money received per pupil from the administration on teachers' salaries, and the rest on its other expenses.

3. Monitoring:

- All pupils take a state exam at age twelve called CITO. An external, independent examining body carries this out. Results are made public and placed on the Internet where everyone has access to them.

- For the evaluation of each pupil, in addition to CITO, the school's own evaluation of each of its pupils is taken into account and the average of the two taken.

- These results make a big difference to pupils' future study options: there are three channels in secondary education.

- Schools with poor results are placed under direct supervision from inspectors, and they are provided with special resources. But if there is no improvement more drastic measures are taken, which may go as far as the school's closure.

- The main task of the inspectorate is to monitor schools and promote improvement.

- PISA and other international evaluations are also used. CITO and PISA results have been found to correlate quite closely.

\section{The Schools}

The most striking features of the system are its autonomy and flexibility. Each school hires whatever staff it needs, determines its own education project, specifies its curriculum, develops its own methodology and procures its resources. Legislation establishes the 'what', while the school is in charge of the 'how' and its implementation. Each school tries its best to respond as adequately as possible to its needs and priorities and those of the neighbourhood, town and circumstances.

\section{Citizens' Rights}

Parents decide which school to send their children to. At the present time, $33 \%$ of schools are public, most of which are run by town councils. Often the council is a shareholder but delegates the school's management to a foundation. $66 \%$ are 'special' schools or social enterprises; the initiative to open these schools may originate from groups of citizens, congregations or foundations of various kinds. Under $1 \%$ are private or special cases.

\section{Three Routes for Secondary Education}

At the end of eight years of primary education, pupils take the CITO exam. The school counsels each pupil on which option to choose for their secondary education. The final decision is taken by the parents:

1. Vocational training (4 years).

2. General secondary ( 5 years).

3. Pre-university (6 years).

\section{Summing Up}

Although this article is based on my own research, especially "Schools and linguistic normalization: some comparative examples" (Rodriguez, [9]), I would not have been able to do this without taking into account both the work done over the years by the journal Hik Hasi and the evaluation data from PISA, obviously. What is PISA? It is an international research programme. Analysing what? Pupils' ability to apply what they have learnt in real life. What is the purpose? What is tested? Reading, the natural sciences and mathematics (2009 language).

Who performs the research? It is organised by OECD, the Organisation for Economic Co-operation and Development. Here is where it is done: 


\begin{tabular}{|c|c|c|c|}
\hline $\begin{array}{l}\text { OECD COUNTRIES } \\
\text { Australia } \\
\text { Austria } \\
\text { Belgium } \\
\text { Canada } \\
\text { Chile } \\
\text { Czech Republic } \\
\text { Denmark } \\
\text { Finland } \\
\text { France } \\
\text { Germany } \\
\text { Greece } \\
\text { Hungary } \\
\text { Iceland } \\
\text { Ireland } \\
\text { Italy } \\
\text { Japan } \\
\text { Korea } \\
\text { Luxembourg } \\
\text { Mexico } \\
\text { Netherlands } \\
\text { New Zealand } \\
\text { Norway } \\
\text { Poland } \\
\text { Portugal } \\
\text { Slovak Republic } \\
\text { Slovenia } \\
\text { Spain } \\
\text { Sweden } \\
\text { Switzerland } \\
\text { Turkey } \\
\text { UK } \\
\text { USA }\end{array}$ & $\begin{array}{l}\text { NON-OECD COUNTRIES } \\
\text { Albania } \\
\text { Argentina } \\
\text { Azerbaijan } \\
\text { Brazil } \\
\text { Bulgaria } \\
\text { China (Taipei) } \\
\text { Colombia } \\
\text { Croatia } \\
\text { Dubai } \\
\text { Estonia } \\
\text { Hong Kong - China } \\
\text { Indonesia } \\
\text { Israel } \\
\text { Jordan } \\
\text { Kazakhstan } \\
\text { Kyrgyzstan } \\
\text { Latvia } \\
\text { Liechtenstein } \\
\text { Lithuania } \\
\text { Macau - China } \\
\text { Montenegro } \\
\text { Panama } \\
\text { Peru } \\
\text { Qatar } \\
\text { Romania } \\
\text { Russian Federation } \\
\text { Serbia } \\
\text { Shanghai - China } \\
\text { Singapore } \\
\text { Thailand } \\
\text { Trinidad and Tobago } \\
\text { Tunisia } \\
\text { Uruquay }\end{array}$ & $\begin{array}{l}\text { AUTONOMOUS COMMUNITIES } \\
\text { Andalucia } \\
\text { Aragon } \\
\text { Asturias } \\
\text { Balearic Islands } \\
\text { Canary Islands } \\
\text { Cantabria } \\
\text { Castile and Leon } \\
\text { Catalonia } \\
\text { Ceuta and Melilla } \\
\text { Euskadi } \\
\text { Galicia } \\
\text { Rioja } \\
\text { Madrid } \\
\text { Murcia } \\
\text { Navarre }\end{array}$ & $\begin{array}{l}\text { OTHERS } \\
\text { Campania } \\
\text { Emilia-Romagna } \\
\text { Flanders } \\
\text { Liguria } \\
\text { Lombardy } \\
\text { Piedmont } \\
\text { Sardinia } \\
\text { Scotland } \\
\text { Sicily } \\
\text { Trento } \\
\text { Veneto } \\
\text { etc. }\end{array}$ \\
\hline
\end{tabular}

The following results for language knowledge and reading were achieved in the countries covered by PISA: PISA 2009. AVERAGE READING SCORES BY COUNTRY

\begin{tabular}{|c|c|}
\hline & \\
\hline Finland & 536 \\
\hline Canada & 524 \\
\hline Japan & 520 \\
\hline Netherlands & 508 \\
\hline Belgium & 506 \\
\hline Norway & 503 \\
\hline Estonia & 501 \\
\hline Switzerland & 501 \\
\hline Poland & 500 \\
\hline USA & 500 \\
\hline Sweden & 497 \\
\hline Germany & 497 \\
\hline Ireland & 496 \\
\hline France & 496 \\
\hline Denmark & 495 \\
\hline Euskadi & 494 \\
\hline UK & 494 \\
\hline Hungary & 494 \\
\hline $\mathrm{OECD}$ & 493 \\
\hline Portugal & 489 \\
\hline Italy & 486 \\
\hline Latvia & 484 \\
\hline Spain & 481 \\
\hline Czech Republic & 478 \\
\hline Slovak Republic & 477 \\
\hline Luxembourg & 472 \\
\hline Lithuania & 468 \\
\hline Turkey & 464 \\
\hline Chile & 449 \\
\hline Bulgaria & 429 \\
\hline
\end{tabular}


So in this article we have looked at Finland, which has stayed at the top of the list year after year; Netherlands, which resembles Euskal Herria and is likewise near the top of the PISA ranking; and another country which is comparable to the Basque Country and has recently achieved independence, Estonia; all of these are European states and education systems which historically have been through period of language contact, and which from a compensatory point of view are model examples of achieving an equilibrium in culturally asymmetrical societies.

An educational structure is needed in the process of forming a Basque state. To help move in that direction, let us look at the Finnish system again and note the following points in particular: people who want to become a teacher must go to university; there are also masters degrees in many specialisations, e.g. special education, art, music and domestic economy; the local councils play a large role. The council plans, builds and maintains schools (a power which was lost in the Spanish state at the beginning of the twentieth century) and hires their staff. One of the characteristics of the Finnish education system is its de-centralisation, and another is the prestige attached to the teaching profession. The cornerstone of their training is thinking and a close link between theory and practice.

In the Netherlands, in addition to passing laws, the state funds and monitors schools. Thus the main task of the inspectors is to monitor the schools and encourage improvement.

In Estonia, after independence, the education system has two main objectives: one is to give all children a school education, the other, to bring children whose mother tongue is not Estonian into the Estonian linguistic fold.

Finally, it should be borne in mind that in these education systems, adult education, institutions of higher education, health and education or the role of the teacher and literacy programmes has been incorporated as core elements of the national system. Thus, with a bilingual situation as the point of departure in all these countries, they have succeeded in extending the right to an education to the entire population adequately, and today obtain some of the highest scores using quality indicators even though not part of the PISA evaluation scheme.

\subsection{Strengths and weaknesses}

Basque education has a tradition of attaching special importance to the education community. The ikastolak, for example, have not only been concerned for the language but have practiced and preached local council participation and civil disobedience in the face of the obligatory imposition of the Spanish and French states' education systems. As we have seen, the Finnish system is based on close links with the town councils and decentralisation (Rodriguez, [7]).

But teacher prestige has been another cornerstone: social attitudes towards Basque teachers in Euskal Herria have been positive, but subordination to the legally determined Spanish curriculum limits their training, turning it into a weakness (Rodriguez, [10]). It is also necessary to build bridges between non-university and university teaching. This is what has been done in the examples cited, and is what was foreseen in the Lizarra Statute of Autonomy of 1931, although present legislation blocks this option, creating another weakness (Rodriguez, [8]).

Reading is one component of the curriculum that is a basic criterion used by PISA to evaluate educational success; but insufficient research has been done in the Basque Country to identify the potential Basque reading audience, nor have proposals been developed to design a reading plan. This is another weakness.

Special education, arts, music and domestic education have been cultivated in Euskal Herria, unlike the surrounding states, and that gives us a point in our favour. Basque teachers have a long tradition of cultivating the link between pedagogical ideas and practice and teachers' in-job training (cf. the journals Isilik and Hik hasi, the teachers' association, ADARRA, the Basque Summer University and so on), and this theoretical practice performed non-institutionally, which has made of re-training a permanent habitus, is another of the sector's strong points.

But opportunities in the Basque Country to pass laws on education have been extremely limited. That is a weakness. The ability to provide schools with money and monitoring, which is the main function of the inspectorate, is ruled out in Euskal Herria because the states reserve this function to themselves. That is another weakness. So there is very little activity to monitor schools and bring about improvements. another weakness.

\subsection{The contributions of a hypothetical state}

In Estonia after independence, the Estonian education system has had two main objectives: to give all children a school education, and to win children whose mother tongue is not Estonian over to Estonian.

In the Basque Country the first of these objectives has been attained but the second has not, and can only be achieved through a new educational legislative arrangement which an independent state would make possible.

To make this clearer and summarise the things that have been explained throughout this article:

To be able to organise the entire organisation of the education system according to the political decisions of the new state, that is: the power to structure the education system by grades, cycles and so on, and the links between them; to decide on terms and criteria for teachers; to set periods of schooling; to manage the organisation of schools with freedom according to needs; to average for pupils in formal education.

Also: to decide minimum teaching contents; to choose Basque as the only language of education; to set curriculum objectives and content; to determine the criteria for evaluation; to legislate general requirements for textbooks.

Consequently, to design necessary qualifications and their equivalences; to determine complete syllabuses 
autonomously; to decide core subjects and fields of study.

And all that, of course, in order to have freedom to organise the teaching structure; to hire school staff and ensure the provision of educational resources. To achieve this, it would be possible to create a full inspectorate to check whether the above conditions are being met, investigate whether there is discrimination against Basque-speaking pupils, and check whether requirements for obtaining qualifications are being complied with.

What is described here are the powers of any state to ensure that educational rights are guaranteed, and of course a hypothetical independent state would need to structure the field of education according to its needs and requirements, which is obviously impossible at present.

In any event, there is one area, besides the power of an independent state to pass laws and regulations in any area, that can be given special attention in the field of language and education, and that is the link between local council policy and education.

We have seen that both with regard to the protection that must be given to the national language and the guaranteeing of local school organisation, the top-ranking countries according to PISA, such as Finland, Canada, the Netherlands, Belgium, Estonia or Switzerland, have opted for a non-centralised school system. To achieve that, at least where the language is concerned, territorial language rights are generally preferred over personal ones (Txillardegi, [12]) and language use in education has been configured according to regional population surveys. In the Basque Country, an educational structure organised according to linguistic registry data has been proposed by Udalbiltza and UEMA, who have now shown how to reorganise councils as described above (Rodriguez, [6]). This offers possibilities for supporting Basque education and culture and developing them as a mainstream national culture, not just as a minority language (Rodriguez, [6]). Thus, rather than the present unending uphill struggle, although there remains much to be done in order to achieve a new organisation of education in the Basque Country, some things have already been done and a hypothetical Basque state has quite a few places to learn from, both inside and outside Euskal Herria.

\section{REFERENCES}

[1] J.L. Alvarez. Sumieraren Normalkuntzaz, Euskal Kulturaren Batzarrea, BAT soziolinguistika aldizkaria, 30, 11-33, 1999.

[2] Finlandiako Hezkuntza Sistema, Xangorin, Hik Hasi Journal of Education, 23, 1-112, 2008.

[3] ISEI-IVEI. PISA txostenaren ebaluazio diagnostikoa: Emaitzen txostena eta aldagaien azterketa, Eusko Jaurlaritza, Spain, 2011.

[4] I. Pikabea, J.F. Lukas. Euskara Ebaluatzeko proba, Xangorin, Hik Hasi Journal, 160, 6-10, 2011.

[5] F. Rodriguez. Hizkuntzen erabilera Europar Batasunari begira, Associaçom Galega da Língua, Agalia journal, 38, 136-148, 1993.

[6] F. Rodriguez. Euskararen herritik erdal mundura, University of the Basque Country, Tanttak Journal, 9, 61-73, 1993.

[7] F. Rodriguez. Ikastolak eta Euskal Eskolak, Orain, Spain, 1996.

[8] F. Rodriguez. Construir o destruir naciones, Besatari, Spain, 1999.

[9] F. Rodriguez. Schools and linguistic normalization: some comparative examples, Universitat Oberta de Catalunya, Digithum, 4, 2002.

[10] F. Rodriguez. Nacionalismo y educación, Delta, Spain, 2011.

[11] F. Rodriguez. Mita kuuluu?, Euskal Idazleen Elkartea, Hegats, 42, 11-25, 2009.

[12] Txillardegi. Hizkuntza/Hezkuntza: Soziolinguistika egunak, University of the Basque Country, 55-62, 1990. 